\title{
A Review of Mechanisms of Implantation
}

\author{
Su-Mi Kim and ${ }^{\dagger} J o n g-S o o ~ K i m$ \\ Dept. of Obstetrics and Gynecology, College of Medicine, Dankook University, Cheonan 31116, Korea
}

\begin{abstract}
Implantation is a highly organized process that involves an interaction between a receptive uterus and a competent blastocyst. In humans, natural fecundity suggests that the chance of conception per cycle is relatively low $(\sim 30 \%)$ and two-third of lost pregnancies occur because of implantation failure. Defective implantation leads to adverse pregnancy outcomes including infertility, spontaneous miscarriage, intrauterine fetal growth restriction and preeclampsia. With use of advanced scientific technologies, gene expression analysis and genetically-engineered animal models have revealed critical cellular networks and molecular pathways. But, because of ethical restrictions and the lack of a mechanistic experiment, comprehensive steps in human implantation have still not been completely understood. This review primarily focuses on the recent advances in mechanisms of implantation. Because infertility is an emerging issue these days, gaining an understanding the molecular and hormonal signaling pathway will improve the outcome of natural pregnancy and assisted reproductive technology.
\end{abstract}

Key words : Implantation, Blastocyst, Endometrium, Uterine receptivity

\section{INTRODUCTION}

Implantation is defined as the process by which the embryo attaches to the endometrial surface of the uterus and invades the epithelium and then the maternal circulation to form the placenta. Before the initiation of implantation, however, both embryo and endometrium should embark on an elaborated process in a time- and location-specific manner. The crosstalk between a receptive uterus and a competent blastocyst can only occur during a limited time span, known as the "window of implantation" (Psychoyos, 1986; Ma et al., 2003). The window of endometrial receptivity is restricted to days $16-22$ of a 28 -day normal menstrual cycle, 5-10 days after the luteinizing hormone (LH) surge (Navot et al., 1991). The uterus then continues into the nonreceptive period for the remaining cycle as the late luteal phase until menstruation ensues. It is not surprising that early pregnancy loss, which occurs during the peri-implantation period before pregnancy is confirmed clinically, is common in humans (Norwitz et al., 2001). The risk of spontaneous abortion significantly increases with implantation beyond this window (Wilcox et al., 1999). The synchronized molecular dialogue mediated by cytokines, a variety of growth factors, prostaglandins, matrix degrading enzymes and their inhibitors, and adhesion molecules is required for successful implantation. Infertility, the inability to conceive within a year of unprotected intercourse, affects one in seven reproductive-aged couples in Korea (Kim et al., 2014). It is necessary to investigate the hierarchical pathways that orchestrate the implantation process to develop solutions for implantation failure and to raise fertility rates in women.

\footnotetext{
Manuscript received November 20, 2017, Received in revised form December 6, 2017, Accepted December 8, 2017

${ }^{\dagger}$ Corresponding Author : Jong-Soo Kim, Ph.D., Department of Obstetrics \& Gynecology, College of Medicine, Dankook University, 359 Manhyangro, Dongnam-gu, Cheonan 31116, Korea. Tel: +82-41-550-6159, Fax: +82-41-556-3878, E-mail: pluripotent77@ gmail.com

This is an Open Access article distributed under the terms of the Creative Commons Attribution Non-Commercial License (http:// creativecommons.org/licenses/by-nc/3.0) which permits unrestricted non-commercial use, distribution, and reproduction in any medium, provided the original work is properly cited.
} 


\section{Preconditions for implantation}

To achieve successful implantation, the uterus should undergo structural and functional remodeling. Estrogen and progesterone are the master hormones mediating these changes. Estrogen and progesterone bind to their respective nuclear receptors. The progesterone receptor exists in two isoforms, PR-A and PR-B, and the estrogen receptor also exists in two isoforms, as ER $\alpha$ and ER $\beta$ (Krege et al., 1998; Mote et al., 2006). In recent years, genetically engineered mouse models have provided information to understand the roles of ovarian steroid hormones during embryo implantation. PR-A is essential for implantation as mice lacking both PR-A and PR-B are infertile, whereas mice lacking only PR-B have normal fertility (Lydon et al., 1995; Mulac-Jericevic et al., 2000). Likewise, ER $\alpha$ is the primary mediator of estrogen action because the uterus of ER $\alpha$ knockout mouse is hypoplastic and they are infertile (Lubahn et al., 1993), while ER $\beta$ knockout mice are fertile (Lee et al., 2012). Progesterone plays a pivotal role in implantation that allows the uterus to support the development of the embryo. The advent of advanced omics technologies provides unique insight of embryo implantation using targeted proteomics by identifying endometrial epithelial cellular and secreted protein changes in response to ovarian steroid hormones (Greening et al., 2016).

The proliferative (follicular) phase is under the influence of rising estrogen levels due to growing ovarian follicles, leading to proliferation of the epithelium, stroma, and vascular endothelium to cause regeneration of the endometrium (Cha et al., 2012). Rising estrogen levels are observed before the receptive phase (Thomas et al., 1973), but it remains to be determined whether this mid-luteal phase estrogen is necessary for implantation in humans or nonhuman primates (Ghosh et al., 1994; Rao et al., 2007). Although estrogen can induce uterine receptivity, the window of implantation remains open for an extended period at lower estrogen levels but rapidly closes at higher levels in the mouse model (Ma et al., 2003). Uterine receptivity is improved when estrogen levels are decreased during the preimplantation period in patients undergoing In Vitro Fertilization and Embryo Transfer (IVF-ET) (Simón et al., 1998b).

Progesterone induces the formation of pinopodes, epithelial cells that lose their polarity and microvilli through down regulation of cell-cell adhesion and develop smooth protrusions along the apical surface (Martel et al., 1987; Thie et al., 1995). The most important feature of pinopodes is removal of the cell surface glycoprotein mucin 1 (MUC1) which inhibits cell to cell adhesion during the window of implantation (Surveyor et al., 1995; Gipson et al., 2008). However, the validity of pinopodes as a marker of uterine receptivity is controversial as pinopodes are detected throughout the luteal phase of the menstrual cycle and in human pregnancy (Quinn \& Casper, 2008).

The early embryo enters the uterine cavity as a morula and becomes a 32 to 256-cell blastocyst before implantation. Implantation begins with the loss of the zona pellucida known as hatching about 1-3 days after the morula enters the uterine cavity in preparation for attachment. The active blastocyst undergoes structure changes such that a more irregular surface with more microvilli is observed with accumulation of glycogen granules in the cytoplasm (Naeslund et al., 1980). In conclusion, the window for successful implantation could be defined as a limited time span when the activated stage of the blastocyst is superimposed on the receptive state of the uterus (Paria et al., 1993a).

\section{Implantation}

Implantation consists of three stages: (a) the blastocyst contacts the implantation site of the endometrium (apposition); (b) trophoblast cells of the blastocyst attach to the receptive endometrial epithelium (adhesion); and (c) invasive trophoblast cells cross the endometrial epithelial basement membrane and invade the endometrial stroma (invasion) (Bischof \& Campana, 1997). 


\section{1) Apposition and adhesion}

Implantation begins with apposition of the blastocyst at the uterine epithelium, generally about 2-4 days after the morula enters the uterine cavity. The implantation site in the human uterus is usually in the upper and posterior wall in the midsagittal plane. Implantation is considered a proinflammatory reaction in which endometrial vascular permeability is markedly increased at the attachment site, mediated by Cyclooxygenase (Cox)-derived prostaglandins. Prostaglandin $E_{2}$ is increased in the luminal epithelium and the underlying stroma at the both of mice and human implantation site, thus indicating its role in attachment and localized endometrial vascular permeability (Van der Weiden et al., 1991; Lim et al., 1997). Prostaglandin $E_{2}$ is considered as one of the important regulators of human trophoblast invasion, which activates other signaling proteins (Nicola et al., 2007). During apposition process, the blastocyst differentiates into an inner cell mass (embryo) and trophectoderm (placenta). Stromal cells surrounding the implanting blastocyst differentiate into a specialized cell type called decidual cells, via a process known as decidualization (Ramathal et al., 2010).

Cytokines are regulatory peptides or glycoproteins. Unlike hormones, cytokines usually act as paracrine or autocrine signals in local tissue, and only occasionally, they have more distant effects as endocrine mediators (McEwan et al., 2009). Leukemia-inhibitory factor (LIF) is a member of the interleukin-6 family of cytokines, which is a major mediator of estrogen action. Knock-out of Lif gene in mice results in infertility, characterized by a defect in implantation and decidualization that can be rescued by administering recombinant LIF (Stewart et al., 1992). Lif expression is higher around the time of implantation in fertile women as opposed to lower levels in infertile women (Laird et al., 1997; Hambartsoumian, 1998). LIF mediates a shift from a proliferative state of luminal epithelium to a differentiated state through down-regulation of cell-cell junctional molecules acting as a barrier to embryo invasion. LIF also drives stromal proliferation through regulation of the epidermal growth factor (EGF) signaling pathway (Hantak et al., 2014). Mice with an inactivating mutation in the colony-stimulating factor-1 (CSF-1) gene are infertile due to lower rates of implantation and fetal viability. Both the embryo and endometrium express CSF-1 receptor mRNA, and it has been suggested that cross-talk of endometrial epithelial CSF-1 with trophectodermal CSF-1 receptor enhances attachment (Pollard et al., 1991). Interleukin-1 (IL1) is considerably involved in implantation and the preimplantation development of the embryo. IL-1 stimulates vascular endothelial growth factor (VEGF) expression and regulates Matrix metalloproteinases (MMPs) and tissue inhibitors of metalloproteinases (TIMPs) (Krüssel et al., 2003). Dominguez et al. observed that Interleukin-6 (IL-6) displayed the highest protein concentration in the endometrial epithelial cell coculture system. Protein microarrays offer a unique platform for the evaluation and identification of multiple protein targets. Upon further assessment of IL-6 using an ELISA-based assay, viable blastocysts were shown to display an in uptake of IL-6 compared with blastocysts that failed to result in a pregnancy, suggesting a potential role for IL-6 in blastocyst development and implantation (Dominguez et al., 2010a; Dominguez et al., 2015b). Heparin-binding epidermal growth factor-like growth factor (HB-EGF) is a crucial molecule in the interactions between the uterus and the embryo during the attachment reaction (Cha et al., 2012). It is expressed exclusively in the luminal epithelium surrounding the blastocyst 6-7 hours before the attachment process in rodents (Das et al., 1994). Its expression is maximal in the receptive epithelium and is concurrent with pinopodes (StavreusEvers et al., 2002). HB-EGF is synthesized as a transmembrane protein that can be processed to release the soluble growth factor, and both forms influence the blastocyst through the EGF family of receptors expressed on the blastocyst surface as a juxtacrine adhesion factor (Raab et al., 1996). HB-EGF also promotes blastocyst growth and zo- 
na-hatching (Paria et al., 1999b).

Cell adhesion of the blastocyst trophectoderm and endometrial luminal epithelial cells of the uterus is mediated by cell adhesion molecules, including integrins, cadherins, selectins, and immunoglobulins (Fukuda \& Sugihara, 2007; McEwan et al., 2009). Cell adhesion molecules are expressed on the surface of invasive trophoblast, and these molecules interact with ligands expressed by the extracellular matrix of the decidua in a temporal and spatial way (Lyall, 2006). Integrins are a family of transmembrane glycoproteins that act as cell surface receptors formed by various combinations of two different, non-covalently linked $\alpha$ and $\beta$ subunits. Menstrual cycle-specific integrins are upregulated in the mid-luteal phase of human endometrium and have been considered as markers of the window of implantation (Lessey et al., 1992). It has been suggested that a lack of integrin expression during the window of implantation can contribute to unexplained infertile women (Klentzeris et al., 1993). The trophoblast also expresses integrins at the time of implantation and at a site of outgrowing trophoblast cells (Sutherland et al., 1993). Cadherins are a family of glycoproteins involved in the $\mathrm{Ca}^{2+}$ dependent cell-cell adhesion mechanism (Takeichi, 1988). In mice, E(epithelial)- cadherin was detected in embryonic cells during the peri-implantation period, and it is also detected in the uterine epithelium (Kadokawa et al., 1989). The presence of E-cadherin in both the trophoblasts and endometrial epithelium indicates that E-cadherin may play an important role in the initial attachment process (Rowlands et al., 2000). Selectins are a group of carbohydratebinding proteins. Although L-selectin was previously thought to be expressed only in hematopoietic cells, human trophoblasts also express L-selectin and its oligosaccharides are expressed in pinopodes (Nejatbakhsh et al., 2012). Interaction between L-selectin on human blastocysts and oligosaccharide ligands on the endometrial epithelium has been proposed as an initial step in implantation (Wang et al., 2008). Blocking L-selectin with specific antibodies leads to impaired adhesion of trophoblasts to the endometrial epithelium (Genbacev et al., 2003). CD98, a component of tetraspanin-enriched microdomians, is a multifunctional type II glycoprotein involved in amino acid transport and cell fusion (Tsurudome \& Ito, 2000; Chillaron et al., 2001). CD98 expression in human endometrium is strictly restricted to the implantation window, and its subcellular localization at the apical surface of endometrial epithelial cells is consistent with a role in blastocyst adhesion (Dominguez et al., 2010c).

\section{2) Invasion}

The process of implantation allows fetal trophoblast cells to invade and migrate into the maternal decidua. By this time, the trophoblasts at the implantation site have formed masses of cytotrophoblasts and syncytiotrophoblasts. Eventually, trophoblast cells destroy the wall of the maternal spiral arteries, converting them from muscular vessels into flaccid sinusoidal sacs lined with endovascular trophoblast (Burrows et al., 1996). The aim of invasion is to reconstruct the maternal spiral arteries, which will maintain a high blood flow between the fetus and the mother, replacing small, high-resistance vessels with large, low-resistance vessels. The extent of trophoblastic invasion determines later placental efficiency and fetal viability in late gestation. Deficiencies in trophoblastic invasion give rise to adverse pregnancy outcomes such as intrauterine growth restriction (IUGR) and preeclampsia (Hunkapiller et al., 2011). Formation of placental villi is associated with remodeling of the extra-cellular matrix through tissue degradation and revision by various proteinases including serine proteases, matrix metalloproteinases (MMPs) and collagenases (Cohen et al., 2006). Serine proteases, including urokinase-type plasminogen activator (uPA) and tissue-type plasminogen activator (TPA) can catalyse the conversion of plasminogen to plasmin for proteolytic degradation of the ECM. Trophoblast cells express plasminogen activator receptors. Invasion and migration of mouse trophoblastic 
cells are closely related to their PA activity (Strickland et al., 1976). The zinc-dependent family of MMPs is a key player in matrix degradation during trophoblastic invasion. The MMP family is classified into three groups, including collagenases, gelatinases, and stromelysins based on the specificity of substrate. Type IV collagen is a fundamental component of the basal membrane and it is one of the major structures of the uterine ECM (Emonard et al., 1990). The invasive capacity of human trophoblastic cells has been shown to correlate with increased production of type IV collagenase (MMP-2 and MMP-9) (Shimonovitz et al., 1994).

During early pregnancy, fetal trophoblast cells invade the uterus and penetrate the basement membrane, a property that is characteristic of malignant cells. However, unlike tumor invasion, trophoblast invasion of the uterus should be under strict control confining the placenta and within the time constraint of a pregnancy. Limitation of trophoblastic invasion is attributed to the balance of activating and inhibiting growth factors, cytokines, and enzymes. Decidual cells produce plasminogen activator inhibitor-1 (PAI-1) which is the major inhibitor of uPA (Schatz et al., 1995; Simón et al., 1996a). The tissue inhibitors of MMPs (TIMPs) tightly regulate the activities of MMPs. Decidual transforming growth factor (TGF)- $\beta$ plays a major regulatory role in limitation of human trophoblast invasion by up-regulating both TIMPs and PAI-1 (Karmakar \& Das, 2002). In addition, TGF- $\beta$ provides antiproliferative signals to differentiate from invasive and proliferative cytotrophoblasts into non-invasive and multinucleated syncytiotrophoblasts at the human fetal-maternal interface (Graham et al., 1992). Decorin, a decidua-derived TGF- $\beta$ binding proteoglycan, negatively regulates proliferation, migration, and invasiveness of human extravillous trophoblast cells in a TGF $\beta$-independent manner (Iacob et al., 2008).

\section{CONCLUSIONS}

In this article, we have discussed about various hor- mones and molecules involved in embryo implantation. They are produced not only in a competent embryo but also in the epithelial and stromal compartments of the uterus. A complex dialogue between a receptive uterus and a competent blastocyst is continued during the implantation period. Many infertility problems have been overcome by a variety of assisted reproductive techniques. But, embryo implantation still remains a major limiting step in the success of In Vitro Fertilization and Embryo Transfer (IVFET). Complete understanding of the molecular pathway of implantation will definitely improve the diagnosis and treatment of infertility. Sensitive and non-invasive methods to detect the embryo quality and endometrial receptivity will help to combat infertility which arises from defective implantation and decidualization.

\section{ACKNOWLEDGEMENTS}

The authors declare that they have no conflicts of interest with respect to this study.

\section{REFERENCES}

Bischof P, Campana A (1997) Trophoblast differentiation and invasion: its significance for human embryo implantation. Early Pregnancy 3:81-95.

Burrows TD, King A, Loke Y (1996) Trophoblast migration during human placental implantation. Hum Reprod Update 2:307-321.

Cha J, Sun X, Dey SK (2012) Mechanisms of implantation: strategies for successful pregnancy. Nat Med 18:17541767.

Chillaron J, Roca R, Valencia A, Zorzano A, Palacin M (2001) Heteromeric amino acid transporters: biochemistry, genetics, and physiology. Am J Physiol Renal Physiol 281:995-1018.

Cohen M, Meisser A, Bischof P (2006) Metalloproteinases and human placental invasiveness. Placenta 27:783-793. 
Das SK, Wang XN, Paria BC, Damm D, Abraham JA, Klagsbrun M, Andrews GK, Dey SK (1994) Heparinbinding EGF-like growth factor gene is induced in the mouse uterus temporally by the blastocyst solely at the site of its apposition: a possible ligand for interaction with blastocyst EGF-receptor in implantation. Development 120:1071-1083.

Dominguez F, Gadea B, Mercader A, Esteban FJ, Pellicer A, Simon C (2010a) Embryologic outcome and secretome profile of implanted blastocysts obtained after coculture in human endometrial epithelial cells versus the sequential system. Fertil Steril 93:774-782.

Dominguez F, Meseguer M, Aparicio-Ruiz B, Piqueras P, Quinonero A, Simon C (2015b) New strategy for diagnosing embryo implantation potential by combining proteomics and time-lapse technologies. Fertil Steril 104: 908-914.

Dominguez F, Simon C, Quinonero A, Ramirez MA, Gonzalez-Munoz E, Burghardt H, Cervero A, Martinez S, Pellicer A, Palacin M, Sanchez-Madrid F, Yanez-Mo M (2010c) Human endometrial CD98 is essential for blastocyst adhesion. PLoS One 5:e13380.

Emonard H, Christiane Y, Smet M, Grimaud J, Foidart JM (1990) Type IV and interstitial collagenolytic activities in normal and malignant trophoblast cells are specifically regulated by the extracellular matrix. Invasion Metastasis 10:170-177.

Fukuda MN, Sugihara K (2007) Signal transduction in human embryo implantation. Cell Cycle 6:1153-1156.

Genbacev OD, Prakobphol A, Foulk RA, Krtolica AR, Ilic D, Singer MS, Yang ZQ, Kiessling LL, Rosen SD, Fisher SJ (2003) Trophoblast L-selectin-mediated adhesion at the maternal-fetal interface. Science 299:405-408.

Ghosh D, De P, Sengupta J (1994) Luteal phase ovarian oestrogen is not essential for implantation and maintenance of pregnancy from surrogate embryo transfer in the rhesus monkey. Hum Reprod 9:629-637.
Gipson IK, Blalock T, Tisdale A, Spurr-Michaud S, Allcorn S, Stavreus-Evers A, Gemzell K (2008) MUC16 is lost from the uterodome (pinopode) surface of the receptive human endometrium: in vitro evidence that MUC16 is a barrier to trophoblast adherence. Biol Reprod 78: 134-142.

Graham CH, Lysiak JJ, McCrae KR, Lala PK (1992) Localization of transforming growth factor- $\beta$ at the human fetal-maternal interface: role in trophoblast growth and differentiation. Biol Reprod 46:561-572.

Greening DW, Nguyen HP, Evans J, Simpson RJ, Salamonsen LA (2016) Modulating the endometrial epithelial proteome and secretome in preparation for pregnancy: The role of ovarian steroid and pregnancy hormones. $\mathrm{J}$ Proteomics 144:99-112.

Hambartsoumian E (1998) Endometrial leukemia inhibitory factor (LIF) as a possible cause of unexplained infertility and multiple failures of implantation. Am J Reprod Immunol 39:137-143.

Hantak AM, Bagchi IC, Bagchi MK (2014) Role of uterine stromal-epithelial crosstalk in embryo implantation. Int J Dev Biol 58:139-146.

Hunkapiller NM, Gasperowicz M, Kapidzic M, Plaks V, Maltepe E, Kitajewski J, Cross JC, Fisher SJ (2011) A role for Notch signaling in trophoblast endovascular invasion and in the pathogenesis of pre-eclampsia. Development 138:2987-2998.

Iacob D, Cai J, Tsonis M, Babwah A, Chakraborty C, Bhattacharjee RN, Lala PK (2008) Decorin-mediated inhibition of proliferation and migration of the human trophoblast via different tyrosine kinase receptors. Endocrinology 149:6187-6197.

Kadokawa Y, Fuketa I, Nose A, Takeichi M, Nakatsuji N (1989) Expression pattern of E-and P-Cadherin in mouse embryos and uteri during the periimplantation period. Dev Growth Differ 31:23-30.

Karmakar S, Das C (2002) Regulation of trophoblast inva- 
sion by IL-1 $\beta$ and TGF- $\beta 1$. Am J Reprod Immunol 48: 210-219.

Kim M, Kim S, Chang SB, Yoo JS, Kim HK, Cho JH (2014) Effect of a mind-body therapeutic program for infertile women repeating in vitro fertilization treatment on uncertainty, anxiety, and implantation rate. Asian Nurs Res 8:49-56.

Klentzeris LD, Bulmer JN, Trejdosiewicz LK, Morrison L, Cooke ID (1993) Infertility: Beta-1 integrin cell adhesion molecules in the endometrium of fertile and infertile women. Hum Reprod 8:1223-1230.

Krüssel JS, Bielfeld P, Polan ML, Simón C (2003) Regulation of embryonic implantation. Eur J Obstet Gynecol Reprod Biol 110:S2-S9.

Krege JH, Hodgin JB, Couse JF, Enmark E, Warner M, Mahler JF, Sar M, Korach KS, Gustafsson JÅ, Smithies O (1998) Generation and reproductive phenotypes of mice lacking estrogen receptor $\beta$. Proc Natl Acad Sci U S A 95:15677-15682.

Laird SM, Tuckerman EM, Dalton CF, Dunphy BC, Li TC, Zhang X (1997) The production of leukaemia inhibitory factor by human endometrium: presence in uterine flushings and production by cells in culture. Hum Reprod 12:569-574.

Lee HR, Kim TH, Choi KC (2012) Functions and physiological roles of two types of estrogen receptors, ER $\alpha$ and ER $\beta$, identified by estrogen receptor knockout mouse. Lab Anim Res 28:71-76.

Lessey BA, Damjanovich L, Coutifaris C, Castelbaum A, Albelda SM, Buck CA (1992) Integrin adhesion molecules in the human endometrium. Correlation with the normal and abnormal menstrual cycle. J Clin Invest 90:188-195.

Lim H, Paria BC, Das SK, Dinchuk JE, Langenbach R, Trzaskos JM, Dey SK (1997) Multiple female reproductive failures in cyclooxygenase 2-deficient mice. Cell 91:197-208.
Lubahn DB, Moyer JS, Golding TS, Couse JF, Korach KS, Smithies O (1993) Alteration of reproductive function but not prenatal sexual development after insertional disruption of the mouse estrogen receptor gene. Proc Natl Acad Sci USA 90:11162-11166.

Lyall F (2006) Mechanisms regulating cytotrophoblast invasion in normal pregnancy and pre-eclampsia. Aust N Z J Obstet Gynaecol 46:266-273.

Lydon JP, DeMayo FJ, Funk CR, Mani SK, Hughes AR, Montgomery CA Jr, Shyamala G, Conneely OM, O' Malley BW (1995) Mice lacking progesterone receptor exhibit pleiotropic reproductive abnormalities. Genes Dev 9:2266-2278.

Ma WG, Song H, Das SK, Paria BC, Dey SK (2003) Estrogen is a critical determinant that specifies the duration of the window of uterine receptivity for implantation. Proc Natl Acad Sci USA 100:2963-2968.

Martel D, Frydman R, Glissant M, Maggioni C, Roche D, Psychoyos A (1987) Scanning electron microscopy of postovulatory human endometrium in spontaneous cycles and cycles stimulated by hormone treatment. J Endocrinol 114:319-324.

McEwan M, Lins RJ, Munro SK, Vincent ZL, Ponnampalam AP, Mitchell MD (2009) Cytokine regulation during the formation of the fetal-maternal interface: Focus on cell-cell adhesion and remodelling of the extracellular matrix. Cytokine Growth Factor Rev 20:241249.

Mote PA, Arnett-Mansfield RL, Gava N, deFazio A, MulacJericevic B, Conneely OM, Clarke CL (2006) Overlapping and distinct expression of progesterone receptors $\mathrm{A}$ and $\mathrm{B}$ in mouse uterus and mammary gland during the estrous cycle. Endocrinology 147:5503-5512.

Mulac-Jericevic B, Mullinax RA, DeMayo FJ, Lydon JP, Conneely OM (2000) Subgroup of reproductive functions of progesterone mediated by progesterone receptor- B isoform. Science 289:1751-1754. 
Naeslund G, Lundkvist O, Nilsson BO (1980) Transmission electron microscopy of mouse blastocysts activated and growth-arrested in vivo and in vitro. Anat Embryol 159: 33-48.

Navot D, Scott RT, Droesch K, Veeck LL, Liu HC, Rosenwaks Z (1991) The window of embryo transfer and the efficiency of human conception in vitro. Fertil Steril 55:114-118.

Nejatbakhsh R, Kabir-Salmani M, Dimitriadis E, Hosseini A, Taheripanah R, Sadeghi Y, Akimoto Y, Iwashita M (2012) Subcellular localization of L-selectin ligand in the endometrium implies a novel function for pinopodes in endometrial receptivity. Reprod Biol Endocrinol 10:46.

Nicola C, Chirpac A, Lala PK, Chakraborty C (2007) Roles of Rho guanosine 5'-triphosphatase A, Rho kinases, and extracellular signal regulated kinase $(1 / 2)$ in prostaglandin E2-mediated migration of first-trimester human extravillous trophoblast. Endocrinology 149:1243-1251.

Norwitz ER, Schust DJ, Fisher SJ (2001) Implantation and the survival of early pregnancy. N Engl J Med 345: 1400-1408.

Paria BC, Huet-Hudson YM, Dey SK (1993a) Blastocyst's state of activity determines the "window" of implantation in the receptive mouse uterus. Proc Natl Acad Sci USA 90:10159-10162.

Paria BC, Elenius K, Klagsbrun M, Dey SK (1999b) Heparin-binding EGF-like growth factor interacts with mouse blastocysts independently of ErbB1: a possible role for heparan sulfate proteoglycans and ErbB4 in blastocyst implantation. Development 126:1997-2005.

Pollard JW, Hunt JS, Wiktor-Jedrzejczak W, Stanley ER (1991) A pregnancy defect in the osteopetrotic (opop) mouse demonstrates the requirement for CSF-1 in female fertility. Dev Biol 148:273-283.

Psychoyos A (1986) Uterine receptivity for nidation. Ann N Y Acad Sci 476:36-42.
Quinn CE, Casper RF (2008) Pinopodes: a questionable role in endometrial receptivity. Hum Reprod Update 15: 229-236.

Raab G, Kover K, Paria BC, Dey SK, Ezzell RM, Klagsbrun M (1996) Mouse preimplantation blastocysts adhere to cells expressing the transmembrane form of heparin-binding EGF-like growth factor. Development 122:637-645.

Ramathal CY, Bagchi IC, Taylor RN, Bagchi MK (2010). Endometrial decidualization: Of mice and men. Semin Reprod Med 28:17-26.

Rao AJ, Ramachandra SG, Ramesh V, Krishnamurthy HN, Ravindranath N, Moudgal NR (2007) Establishment of the need for oestrogen during implantation in non-human primates. Reprod Biomed Online 14:563-571.

Rowlands TM, Symonds JM, Farookhi R, Blaschuk OW (2000) Cadherins: Crucial regulators of structure and function in reproductive tissues. Rev Reprod 5:53-61.

Schatz F, Aigner S, Papp C, Toth-Pal E, Hausknecht V, Lockwood CJ (1995) Plasminogen activator activity during decidualization of human endometrial stromal cells is regulated by plasminogen activator inhibitor 1 . J Clin Endocrinol Metab 80:2504-2510.

Shimonovitz S, Hurwitz A, Dushnik M, Anteby E, GevaEldar T, Yagel S (1994) Developmental regulation of the expression of 72 and $92 \mathrm{kd}$ type IV collagenases in human trophoblasts: A possible mechanism for control of trophoblast invasion. Am J Obstet Gynecol 171: 832838.

Simón C, Gimeno MJ, Mercader A, Francés A, Garcia Velasco J, Remohí J, Polan ML, Pellicer A (1996) Cytokines-adhesion molecules-invasive proteinases. The missing paracrine/autocrine link in embryonic implantation? Mol Hum Reprod 2:405-424.

Simón C, Garcia Velasco JJ, Valbuena D, Peinado JA, Moreno C, Remohí J, Pellicer A (1998) Increasing uterine receptivity by decreasing estradiol levels during the 
preimplantation period in high responders with the use of a follicle-stimulating hormone step-down regimen. Fertil Steril 70:234-239.

Stavreus-Evers A, Aghajanova L, Brismar H, Eriksson H, Landgren BM, Hovatta O (2002) Co-existence of heparin-binding epidermal growth factor-like growth factor and pinopodes in human endometrium at the time of implantation. Mol Hum Reprod 8:765-769.

Stewart CL, Kaspar P, Brunet LJ, Bhatt H, Gadi I, Kontgen F, Abbondanzo SJ (1992) Blastocyst implantation depends on maternal expression of leukaemia inhibitory factor. Nature 359:76-79.

Strickland S, Reich E, Sherman MI (1976) Plasminogen activator in early embryogenesis: enzyme production by trophoblast and parietal endoderm. Cell 9:231-240.

Surveyor GA, Gendler SJ, Pemberton L, Das SK, Chakraborty I, Julian J, Pimental RA, Wegner CC, Dey SK, Carson DD (1995) Expression and steroid hormonal control of Muc-1 in the mouse uterus. Endocrinology 136:3639-3647.

Sutherland AE, Calarco PG, Damsky CH (1993) Developmental regulation of integrin expression at the time of implantation in the mouse embryo. Development 119: 1175-1186.

Takeichi M (1988) The cadherins: cell-cell adhesion mo- lecules controlling animal morphogenesis. Development 102:639-655.

Thie M, Harrach-Ruprecht B, Sauer H, Fuchs P, Albers A, Denker HW (1995) Cell adhesion to the apical pole of epithelium: a function of cell polarity. Eur J Cell Biol 66:180-191.

Thomas K, De Hertogh R, Pizarro M, Van Exter C, Ferin J (1973) Plasma LH-HCG, 17-estradiol, estrone and progesterone monitoring around ovulation and subsequent nidation. Int J Fertil 18:65-73.

Tsurudome M, Ito Y (2000) Function of fusion regulatory proteins (FRPs) in immune cells and virus-infected cells. Crit Rev Immunol 20:167-196.

Van der Weiden RM, Helmerhorst FM, Keirse MJ (1991) Influence of prostaglandins and platelet activating factor on implantation. Hum Reprod 6:436-442.

Wang B, Sheng JZ, He RH, Qian YL, Jin F, Huang HF (2008) High expression of 1-selectin ligand in secretory endometrium is associated with better endometrial receptivity and facilitates embryo implantation in human being. Am J Reprod Immunol 60:127-134.

Wilcox AJ, Baird DD, Weinberg CR (1999) Time of implantation of the conceptus and loss of pregnancy. $\mathrm{N}$ Engl J Med 1999:1796-1799. 